\title{
"NONEQUILIBRIUM SULFUR CAPTURE \& RETENTION IN AN AIR COOLED SLAGGING COAL COMBUSTOR
}

First Quarterly Technical Progress Report

DOE Contract No:: DE-AC22-95PC95102

Contract Period of Performance: 9/14/95 to 9/13/97

Period Covered by Report: September 14,1995 to December 31,1995

Contractor: Coal Tech Corp.

P.O.Box 154, Merion Station, PA 19066

Principal Investigator: Dr.Bert Zauderer, Phone No.(610) 667-0442

Date Submitted: February 10, 1996

Prepared for

PETC Project Manager: Andrew Karash

Pittsburgh Energy Technology Center

U.S.Department of Energy

P.O.Box 10940

Pittsburgh,PA 15236

DISCLAIMER

This report was prepared as an account of work sponsored by an agency of the United States Government. Neither the United States Government nor any agency thereof, nor any of their employees, makes any warranty, express or implied, or assumes any legal liability or responsibility for the accuracy, completeness, or usefulness of any information, apparatus, product, or process disclosed, or represents that its use would not infringe privately owned rights. Reference herein to any specific commercial product, process, or service by trade name, trademark, manufacturer, or otherwise does not necessarily constitute or imply its endorsement, recommendation, or favoring by the United States Government or any agency thereof. The views and opinions of authors expressed herein do not necessarily state or reflect those of the

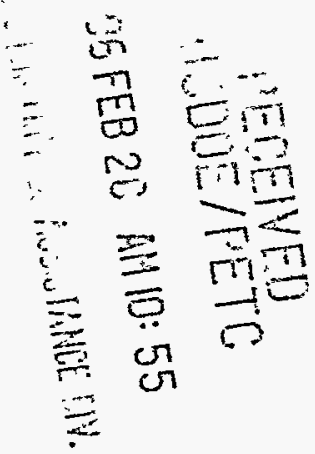
United States Government or any agency thereof.

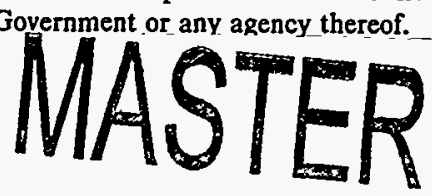




\section{TABLE OF CONTENTS}

1. SUMMARY

2. PROJECT DESCRIPTION

2.1. Objectives

2.2. Technical Approach

2.2.1. Overview of the Work

2.2.2. Task Description
PAGE

1

2

2

2

2

3

5

5

5

4. EFFORT OF THE NEXT QUARTER 


\section{SUMMARY}

The objective of this 24 month project is to determine the degree of sulfur retention in slag in a full scale cyclone coal combustor. This effort will consist of a series of up to 20 parametric tests in a $20 \mathrm{MMBtu} / \mathrm{hr}$ slagging, air cooled, cyclone combustor. During the present reporting period, this combustor was in the final stages of re-installation in a new facility in Philadelphia, PA following its relocation from a test facility in Williamsport, PA. Initial shakedown test on this new combustor facility began in December 1995, at the end of the present quarterly reporting period. The shakedown tests will continue through the next quarterly reporting period in the first three months of calendar year 1996. This installation and shakedown test work is being implemented under another DOE project. After these shakedown tests are completed, test work will commence in the present project. Commencement of test work also requires approval by DOE of the environmental questionnaire. Based on the initial results of the shakedown tests in the new combustor facility, it is anticipated that the test effort, analysis, and final report on the present project can be implemented within the scheduled 24 month duration of this project. 


\section{PROJECT DESCRIPTION}

\subsection{Objectives}

The primary project objective is to determine the degree of sulfur retention in slag in a full scale cyclone coal combustor. This non-equilibrium process is a key step in the capture and retention of sulfur released during coal combustion by the interaction with calcium based sorbent particles. By encapsulating the sulfur bearing calcium particles in slag, the need for landfilling of this waste is eliminated. This objective will be implemented through a series of up to 20 one day tests carried out in a $20 \mathrm{MMBtu} / \mathrm{hr}$ air cooled, slagging combustor-boiler installation located in Philadelphia, PA. The project will consist of two tasks. Task 1 consist of the experiments conducted in the $20 \mathrm{MMBtu} / \mathrm{hr}$ combustor, and task 2 will consist of analysis of this data. All the operating procedures for this effort have been developed in the 7 years of operation of this combustor.

\subsection{Technical Approach}

\subsubsection{Overview of the Work}

The work of this Phase 3 project will be implemented on Coal Tech's patented, 20 MMBtu/hr, air cooled cyclone coal combustor that is being installed on an oil designed, package boiler at a new facility at the Arsenal Business Center in Philadelphia, PA. This new facility consists of a refurbished and upgraded $20 \mathrm{MMBtu} / \mathrm{hr}$ combustor that had been tested at a manufacturing plant in Williamsport, PA from 1987 through 1993. The primary fuel has been, and will remain, coal. Other tests, including combustion of refuse derived fuels and vitrification of fly ash, have been successfully performed. Additional ash injection may be required to achieve high sulfur retention in the slag in the present combustor tests.

The combustor's novel features are air cooling and internal control of $\mathrm{SO}_{2}, \mathrm{NO}_{\mathbf{x}}$, and particulates. Air cooling, which regenerates the heat losses in the combustor, results in a higher efficiency and more compact combustor than similar water cooled combustors. Internal control of pollutants is accomplished by creating a high swirl in the combustor which traps most of the mineral matter injected in the combustor and converts it to a liquid slag that is removed from the floor of the combustor.

$\mathrm{SO}_{2}$ is controlled by injecting calcium oxide based sorbents into the combustor to react with sulfur emitted during combustion. The spent sorbent is dissolved in the slag and removed with it, thereby encapsulating the sulfur in slag. Part of the sorbent exits the combustor with the combustion products into the boiler where it can react with the sulfur. The primary objective of the present tests is to maximize the degree of sulfur retention in the slag. All spent sorbent not reporting to the slag is either deposits in the boiler or it is removed in the stack particle scrubber.

$\mathrm{NO}_{\mathrm{x}}$ is controlled by staged, fuel rich combustion inside the combustor. Additional reductions are achievable by reburning in the boiler or by ammonia injection if the stack gases. 
Excellent progress had been made prior to the start of the present project in meeting several of these combustor performance objectives. One of the most important objectives of this technology development effort is to demonstrate very high $\mathrm{SO}_{2}$ reduction in the combustor. Prior to the start of the present project, the peak $\mathrm{SO}_{2}$ reduction achieved with sorbent injection in the combustor had been $90 \%$. Of this amount a maximum of $11 \%$ of the total coal sulfur was trapped in the slag. Evaluation of this prior data indicated that the low sulfur retention in the slag was due to excessive slag residence time in the combustor. Since the solubility of sulfur in slag is low, long slag residence times (in excess of 5 minutes) can result in substantial sulfur gas re-evolution into the gas phase.

To reduce the slag time in the combustor in the present project tests, the slag mass flow rate will be increased by either using very high ash coals or by injection coal ash with the coal. High ash mass flow rates increase the slag flow rate.

In order to determine the non-equilibrium sulfur-slag chemistry, calcium sulfate (anhydrite) will be injected into the combustor to vary the slag flow rate inside the combustor and to measure the sulfur gas evolution rate independently of the calcium-sulfur heterogeneous capture reaction. This information will then be used to measure the combined sorbent-sulfur capture rate in the gas phase with the sulfur retention rate in the slag inside the combustor.

The 20 tests planned for this project will allow full parametric variation of these sulfursorbent capture and sulfur-slag re-evolution reactions.

\subsubsection{Task Description}

\section{Task 1: Sulfur Chemistry Tests in the Slag of a Cyclone Combustor.}

This task will consist of four groups of tests designed to validate the sulfur chemistry in slag under non-equilibrium conditions. The tests are designed to validate the chemical and fluid mechanical processes occurring in the capture and retention of sulfur in slag. These reactions are based on prior analytical and experimental work in coal slags and coal like slags, such as steel blast furnace slags. The plan calls for a total of 20 one day tests. However, due to resource limitations, it is planned to accomplish the project objectives in as few as 15 one day tests. To meet all the parametric test variations, the duration of individual test conditions will be reduced.

In the first group of six tests, anhydrite will be injected into the $20 \mathrm{MMBtu} / \mathrm{hr}$ combustor at a rate that duplicates the complete reaction of sulfur from a $\mathbf{2 \%}$ sulfur coal with calcined calcium oxide particles. While maintaining this sulfur concentration fixed, the total slag mass flow rate will be increased in three discrete steps, with each step remaining fixed for the entire 6 hour, one day test period. Both fuel rich and fuel lean operation will be tested. The purpose of these tests and the second group of tests is to measure sulfur re-evolution from a sulfur based calcium compound at concentrations that duplicate the maximum amount of sulfur that can be captured in the combustor with calcium oxide sorbents. 
In the second group of six tests, anhydrite will be injected into the $20 \mathrm{MMBtu} / \mathrm{hr}$ combustor at a rate that duplicates the complete reaction of sulfur from a $4 \%$ sulfur coal with calcined calcium oxide particles. While maintaining this sulfur concentration fixed, the total slag mass flow rate will be increased in three discrete steps, with each step remaining fixed for the entire 6 hour, one day test period.

These two groups of tests will determine the sulfur retention capability of slag as a function of slag residence time in a commercial scale combustor, namely the unit rated at 20 MMBtu/hr. In other words these tests will focus only on the sulfur retention in slag. This type of test was performed briefly in the $20 \mathrm{MMBtu} / \mathrm{hr}$ combustor facility and the results indicated that this is an effective method for studying sulfur retention in slagging cyclone combustors.

In the third group of four tests, the entire sulfur capture process will be implemented from the injection of the uncalcined sorbent to its reaction in the combustor and impact and removal with the slag. The slag mass flow rate will be adjusted to duplicate the optimum slag flow rate determined from the group one tests. These fuel rich and fuel lean tests will serve to validate the entire sulfur capture and retention process in the combustor.

In the final group of four one day tests, reacted sorbent collected in the boiler and stack baghouse will be injected into the combustor at the optimum slag mass flow rate determined from the first two groups of tests. The objective of this test series will be to determine the degree of sulfur encapsulation in slag in cases where the magnitude of sulfur capture with injection of sorbent in the combustor is insufficient to meet environmental emission standards.

All the experiments will be conducted in accordance with the procedures developed in the seven years of testing in Williamsport and in the current tests in Philadelphia on the $20 \mathrm{MMBtu} / \mathrm{hr}$ combustor.

\section{Task 2: Analysis}

The results of the tests in task 2 will be analyzed using two and three dimensional combustion codes for the conditions existing in this combustor, and a code for analyzing slag flow on the walls of the combustor. The results will be compared with prior tests in the present combustor and with laboratory scale data on the sulfur chemistry process in coal and steel slags.

The analytical procedures and bench scale tests on sulfur-slag reactions developed in prior decades will be used for this purpose. 


\section{PROJECT STATUS}

\subsection{Effort of the Present Quarter}

During the present reporting period this combustor was in the final stages of re-installation in a new facility in Philadelphia, PA following its relocation from a test facility in Williamsport, PA. Initial shakedown test on this new combustor facility began in December 1995, at the end of the present quarterly reporting period. The shakedown tests will continue through the next quarterly reporting period in the first three months of calendar year 1996. The installation and shakedown test work is being implemented under another DOE project. After these shakedown tests are completed, test work will commence on the present project. Commencement of test work will follow after approval by DOE of the environmental questionnaire.

Based on the initial results of the shakedown tests in the new combustor facility, it is anticipated that the test effort, analysis, and final report on the present project can be implemented within the scheduled 24 month duration of this project.

\section{EFFORT OF THE NEXT QUARTER}

During the next quarterly reporting period, the results of the initial shakedown tests on the $20 \mathrm{MMBtu} / \mathrm{hr}$ combustor that are being performed under another DOE project will be used to finalize the test plan for the present combustor. Pending final approval by DOE of the Environmental Questionnaire, the first combustor tests under present project will be initiated. 